\title{
Role of Peer-Group in Selective Exposure About Pornography through Internet Among Teenagers of Modern Islamic Boarding School in Tangerang City
}

\author{
Her Sanyoto ${ }^{1}$, Inge Hutagalung ${ }^{2}$ \\ \{deeng.sanyoto@tanihub.com ${ }^{1}$, inge_hutagalung@yahoo.com / inge_hutagalung@mercubuana.ac.id ${ }^{2}$ \} \\ Universitas Mercu Buana, Indonesia ${ }^{1,2}$
}

\begin{abstract}
Understanding how vital peer group can influence teens to seek of sex information, it would be interesting to have a study what is the role of peer group among teens on selective exposure of pornographic information through internet. This research involved students from an Islamic boarding school in Tangerang city as informants. Tangerang was chosen because it is located near Jakarta, the capital city which placed fifth in the list of cities that accesses most the "sex" keyword. Argumentation of researcher to choose Islamic boarding school is to know whether peer group could affect the process of selective exposure on pornographic information among students, instead of tradition of obedience and discipline of Islamic boarding school. The framework of thinking in this research is based on the constructivist paradigm. A qualitative approach was applied in this research. The data collection techniques used in-depth interview method. The result of the study shows that peer group does not play a role in the process of selective exposure on pornographic information in Islamic boarding school instead other factor that affect the student are the normative belief based on parenting system and rules of the Islamic boarding school.
\end{abstract}

Keywords: Pornography, Group Support, Rules of Islamic Boarding School.

\section{Introduction}

According to a survey conducted by Google Trends in 2010, Indonesia placed fifth in the list of countries with the most search of the keyword "sex". The survey also reported that DKI Jakarta, the capital city of Indonesia, contributes the most searches for this particular keyword in Indonesia (news.mypangandaran.com, 18 April 2019).

The Ministry of Communication and Informatics (Kominfo RI) also reported that Indonesia has more than 62 millions internet users. It is approximated that $80 \%$ of internet users are aged 15-30 years old, and $85 \%$ to $97 \%$ of them accesses pornographic content(s). According to the Indonesian labor law, a minor is categorized as a teenager when they reach the age of 16-18 or if they have already been married and owns a place of living. From these reports and definitions, it could be concluded that teenagers are the dominant users of pornographic contents (beritasatu.com, 18 April 2019).

In addition to the Kominfo RI's survey, the survey conducted by the Indonesian Commission for Child Protection (KPAI), that involves 4.500 middle-schoolers and highschoolers as respondents, also revealed that $97 \%$ of the students have accessed pornographic contents. Other similar survey had also been conducted, such as the one done by Yayasan 
Anak, which shows that $85 \%$ of students in Jabodetabek have accessed pornographic contents (beritasatu.com, 18 April 2019).

Furthermore, as discussed previously, Indonesia placed fifth in the list of countries with the most search of the keyword "sex". Jakarta, the capital city of Indonesia, also placed fourth in the list of cities with the most "sex" keyword search, just below three other cities: Delhi, Hanoi, Mumbai. This fact is concerning because after further research was conducted, students are the biggest user of pornographic contents (kompasiana.com/25 Juni 2015).

Pornography has a severe adverse effect because pornography could increase the number of sexually active teenagers. This increase in the number of sexually active teenagers also created other problems such as unwanted pregnancy and abortion, which is seen as the solution to unwanted pregnancy. Abortion is a risky process, especially the effect it can cause to the reproductive system. Abortion could cause medical complication such as hemorrhage, infection, and poisoning caused by the tools/substances used to do abortion. The injury to the genitalia and permanent damage to the reproductive system from abortion could cause infertility or even death (Damayanti, 2007; Supriati \& Fikawati, 2009).

Pornography could also negatively affect brain growth of the person who accesses it. Pornography has a severe adverse effect because it can damage five brain part, especially prefrontal cortex which is located near the frontal bone, continuous excessive stimulation without filter from pornography could permanently damage this logical part of the brain. This could lead to some symptoms such as boredness, the feeling of isolation, anger, feeling pressured, and tiredness. Other than that, another concerning effect of pornography is how it can negatively affect students' academic performance, study skills, and decision-making skills (Republika.co.id, 23 April 2019).

Taking into account the adverse effects of pornography, a particular question of "Why teenagers keep accessing pornographic information?" emerged.

Some research articles by Anisah, Hutagalung, and Mahsiani (Anisah, 2016; Hutagalung, 2017; Mahsiani, 2018) stated that teenagers access pornographic information because they find it hard to find information about sex. To ask their parents about sex is seen as a taboo thing to do, and there is an embarrassing aspect when asking their teachers. Because of this, students try to find information about sex through pornographic contents on the internet with their peer group.

Furthermore, research articles by Dohyun and Hutagalung (Ahn, 2010; Hutagalung, 2016a) stated that the decision process of accessing pornographic information which is facilitated by peer-group pressure is in line with the thought of Littlejohn (Littlejohn \& Foss, 2009) on information processing system; individual decisions are not only affected by selfcognitive system but also external aspects such as peer-group pressure.

For teenagers, their closeness level with their peer-group is exceptionally high. Aside from the fact that their peer-group relationship could substitute their family relationship, peergroup could also be the main source of a particular teenager affection, sympathy, understanding, experience-sharing, and a place for teenagers to achieve autonomy and independence (Hutagalung, 2018; Sarwono, n.d.)

Understanding how vital peer-group could be in affecting the teenager's decision-making process, it would be interesting to investigate what is the role of peer-group on teenager's pornographic contents selective exposure. This research involved students from an Islamic boarding school in Tangerang city as respondents. Tangerang was chosen because it is located just near Jakarta, the city which placed fifth in the list of cities that accesses the "sex" keyword the most. This research also chose Islamic boarding school to see better the peer-group factor 
on pornographic contents selective exposure, because Islamic boarding school has a culture of obedience and discipline.

\section{Literature Review}

\subsection{The Selective Exposure Theory}

Festinger's dissonance theory has established that one form of communicational behavior that an individual could engage in to alleviate dissonance is to search and reject information (selective exposure). Through the selective behavior hypothesis, Festinger predicted that every individual will reject information that could cause dissonance, and will prefer to look for information that will support their beliefs.

In another word, it could be said that there is two central aspects inside the selective exposure concept: the ability of an individual to select information(s) that is in-line with their beliefs (selectivity) and the ability of an individual to reject information(s) that contradicts their beliefs (avoidance).

In its core, selective exposure could be seen as an individual's process of selecting wanted or unwanted information. Nowadays, information is more and more available and individual will select whichever information they would or would not access (Fischer, Peter, 2011).

Festinger's (1957) selective exposure hypothesis puts individual psychological condition as the main motivator for why someone handles information selectively. This hypothesis put an individual as an active information processor that has an inherent ability to select or reject information in order to achieve cognitive alignment. This condition could be seen to have a similarity with the cognitive dissonance theory (as the main building blocks for selective exposure) that is known as a theory that has individualism aspect to it, where dissonance happens individually (Littlejohn \& Foss, 2009; Miller, 2005)

If Festinger (Festinger, 1957) emphasized the psychological aspect (beliefs), other researchers tried to prove other aspects outside the psychological one as the trigger for selective exposure. A set of research was conducted by some expert to prove that selective exposure is not caused only by the psychological aspect. The message and the social aspect could also affect the selection or avoidance of information (s) (Hutagalung, 2018).

This finding is in line with the previous theoretical thought by communication experts, such as McQuail and Festinger (Festinger, 1957; McQuail, 1996). The main takeaway is that these experts stated that inside an information processing system, an individual is not only affected by internal (self) cognitive system but also external factors such as the social environment or the characteristics of the message. Individuals, in their process of information processing, is not only affected by internal psychological factor but is also affected by social interaction, which is what social beings do.

In this case, individuals will try to achieve cognitive balance by avoiding or reducing the dissonance. When particular information has no social support/endorsement, then an individual will tend to avoid and reject this information because it could trigger cognitive dissonance. And vice versa, if an information that is already rejected by an individual but being endorsed by the group this individual is in, the individual could change their belief and accepts their previously rejected information, all of this is done to achieve cognitive balance with the group (Festinger, 1957; Griffin, 2009; Littlejohn \& Foss, 2009; Zillmann \& Bryant, 1985). 
From this explanation, it could be seen that group support/endorsement of information could potentially affect the change of an individual's beliefs, other than the selective exposure factor.

\subsection{The Social Identity Theory}

The social identity theory explained how an individual's behavior could be influenced by a group this particular individual is in. This theory is formulated to explain why and how individuals identify themselves with particular social groups; this theory also provides an explanation of how this identifying process could affect an individual's perception and behavior. According to the social identity theory, a person is not a mere "self" but rather some few personal selves, depending on how many this individual's social circles. The different social context could trigger individuals to think, feel, and behave differently (Tajfel, H., \& Turner, 1979).

Furthermore, when social identity is functioning, the individual will try to behave in accordance with their social group subjective norms.

Groups tend to share some rules or standards, which are norms that are applied to different aspects of human behavior. When someone joins a particular social group, whether they realized it or not, they actually agree on some set of rules or standards created by the group. This condition creates subjective norms, the individual beliefs of what does important people in their circles expect from them. Emerging from the subjective norm, someone will also have normative belief, an individual's belief of how their important referent (family, friends, or reference group) will support their behavior that is in-line with the subjective norm, and vice versa, behavior that contradicts the subjective norms will not be supported by their referent. The consequences of not adhering to the subjective norms are moral consequences (ostracized, ridiculed, excluded from the group) and legal consequences (Fishbein, M., \& Ajzen, 1975).

Scientific researches on the effect of group norms on individuals behavior had already started since 1930, especially with the findings presented by Muzafer Sheriff $(1936,1937)$. Sheriff's research was addressing the autokinetic light effect. From his experiment, Sheriff concluded that groups tend to agree on something and then defends that agreement, even if the agreement was false or is not true at all. Sheriff's research also explained how group pressure has a very big influence on how individuals assess the information they are receiving. Sheriff's research shown how the social environment affected the individual's judgment on stimuli given in the experiment. Social environment will create an internal reference point or anchor point, which could decide which behavioral changes that would be accepted or rejected by an individual (Griffin, 2009; Severin \& Tankard Jr., 2001).

A study was conducted in the 1940s by Paul Lazarsfeld et al. in the Bureau of Applied Social Research in the Columbia University strengthen Sheriff's findings. Lazarsfeld's research original purpose is to understand the voters behavior in Erie County, Ohio, in the 1940's Roosevelt and Wilkie election (Lazarfeld, Berelson, and Gaudet, 1968), and voters in Elmira, New York, in the 1948's Truman and Dewey election (Berelson, Lazarsfeld, and McPhee, 1954). This research finds that mass media had a relatively low impact in changing voters opinion compared to the internal self factor or the group influence factor. This research has shown that there is a strong tendency for an individual to vote the same candidate as their primary group did. Family is one of the most critical components in the primary group; $75 \%$ of the first voter in the Elmira study gave the same vote as their father. People also tend to give the same vote as their workgroup. Berelson, Lazarsfeld, and McPhee (1954) stated that 
this strong consistency as "Political Homogeneity in Primary Groups" (Severin \& Tankard Jr., 2001)

\section{Methodology}

The framework of thinking in this research are based on the constructivist paradigm. A qualitative approach was employed in this research. The data collection techniques used indepth interview method. This method was chosen because pornography is a sensitive and personal issue.

The informants or the interviewee for this study are teenagers from an Islamic boarding school in Tangerang city. Tangerang was chosen because it is located just near Jakarta, the city which placed fifth in the list of cities that accesses the "sex" keyword the most.

\section{Results and Finding}

\subsection{Results}

There were six informants in this study. For presentation purposes, all six informants used agreed initials, four of the informants were male with the initials of TN, HS, AL, and AM, the rest two informants were female with the initials of RT and DW.

\subsubsection{Understanding of Pornography}

In the context of this study, all informants stated that pornography is information about sexuality and women's body exploitations. Here is a statement from one of the informants:

"Pornography is information about sexuality. Pornography often exploited women's body parts. I am also confused by the fact that pornography uses women as the object for pornographic information. In my understanding, pornography is prohibited by the government. My religion and my parents also prohibit me from accessing pornography, even though I am not sure why they (the parents) did that. I think there are a lot of sexual problems related to the teenager biological development that our parents or teachers could help us answers." (Informant TN). 


\subsubsection{Pornography Information Source}

In the context of this study, the informants acquire pornographic information through internet, smartphone, or even from conversations with their friends. Here is a statement from one of the informants:

" I acknowledge that pornography is prohibited, but we (students) still need information about sexuality. Honestly, I realized the danger of pornographic information, but my peers often talk about pornography when we gathered together. If I do not join the group conversation, I would be embarrassed and my peers would avoid me, so I also look for pornographic information to fit in. I look for pornographic information on the internet. Even the Indonesian government has already banned pornographic sites. Usually the internet cafe's workers still have a way to access it (pornography)" (Informant AL).

\subsubsection{The Curiosity About Pornography}

In the context of this study, all male informants (TN, HS, AL, AM) stated that they have some curiosity about pornography, while the two female informants strongly expressed their disgust toward pornographic contents and do not have any curiosity about pornography, here is a statement from one of the male informants:

"I would really like to know more pornographic information. There are a lot of sexual things that happened to me, but I do not have the answer to it. I got ignored when I asked my parents and are embarrassed when asking my teachers. So, for me, the solution is to talk with my peers, we talked about random stuff, but the most essential part is our experience sharing"(Informant AM).

Meanwhile, here is a statement from one of the female informants:

" I don't want to watch pornography; It disgusts me! Me, as a woman, felt ashamed and insulted seeing pornographic information. I often think about why only women that are objectified in pornography? Why do they want to do it? My point is, I am not interested and do not want to know about pornography. Sex issues is a natural thing for me, where everyone would encounter in their adult age. No need to 'learn' about it.." (Informant DW)

\subsubsection{The Benefit of Pornographic Information}

In the context of this study, there are two main opinions from the informants. Our female informants do not see any benefit in pornographic information, while our male informants expressed that pornographic information has its value, especially in giving them education about sexuality. Here are both statement representing both sides of opinion:

"Pornographic information has no benefit at all. Pornography is prohibited by law; my parents do not allow me to look for pornographic information. (my) Religion is also condemning pornography. So, I think there is no benefit at all coming from pornography; it could instead poison and destroys the young generation" (Informant DW).

"Pornographic information is very beneficial. A lot of information regarding physical development and sex that we can learn from pornographic information: we, as the young generation, especially males, experience the puberty phase which resulted in physical changes, but there is no information source that could explain why these changes happen and how should we respond to it. My friends and I realized that pornography could make us addicted; we talk about this (effect) a lot in our group conversation" (Informant HS). 


\subsubsection{Peer-Group Support Towards Pornography Selective Exposure}

In the context of this study, informants stated that peer-group has its role in the process of selection or avoidance of pornography, here are the statements from the informants:

" As I said previously, one reason for me to look for pornographic information is peergroup. My peer-group where I hang out often talk and discuss pornography so I would need to look for pornographic information in order to keep up with the discussion. I get embarrassed when I am not up-to-date with pornographic information." (Informant AL).

"Peer-group is the place for me to get together with my friends, expressed my feelings, and it's a part of me now. For me, the group decision has to be followed. Regarding pornographic information, if my peer-group endorsed it, then I as a member will also look for pornographic information, and vice-versa. I think that obedience to peer-group is a must" (Informant AM).

\subsubsection{The Compliance Toward the Boarding School Rules About Pornography}

In the context of this study, the informants agreed on how they are very complying towards the boarding school rules about pornography. They understand fully what is prohibited and what is allowed to do in their school, and will adhere to it. Here are some of their opinions:

" As I said, group rules have to be followed. Other than peer-group, there is also a bigger group, the community of my boarding school. My Islamic Boarding School has a clear law about pornography, and that's the law that I will adhere to. Because peer-group is only temporary, but my boarding school will be a group that is permanent because it's a part of me and when I graduated, the diploma will be a symbol for that permanency" (informant AM)

"If I had to choose whether to follow peer-group rules or the boarding school rules. Of course, I would choose to follow the boarding school rules. Why? Because I think peer-group is also a part of the boarding school. This means that the boarding school rules would influence the rules inside the peer-group. Peer-group has to be in-line with the boarding school. Because obviously, if I am not adhering to the boarding school rules, I would get kicked out. And I don't want that; my primary purpose is to get an education in this boarding school, not to make a peer-group" (Informant AL).

\subsection{Findings}

From the previous section, we can see that the informants have already understood the concept of pornography. Their understanding is in-line with the Indonesian law of UndangUndang Pornografi No. 44 Tahun 2008, which states that pornography is information which contains lewdness or sexual exploitation that contradicts the society norms.

There is also the source of pornographic information for the informants, mainly from the internet and conversation inside the peer-group. Because there is limited information about sexuality, many teenagers are in confusion to find a place to ask and have difficulty accessing the right sources of information about sex. In order to acquire reliable answers about their sexual questions, amid the controversy over whether sex information is needed for adolescents, teenagers tend to seek sex information from peer-groups and the mass media.

For teenagers, their closeness to peer-groups is very high because, in addition to how peer-group ties could temporarily substitute family ties, they are also a source of affection, 
sympathy, and understanding, teenagers can share each other experiences inside their peergroups, the peer-groups is also a place for teenagers to achieve autonomy and independence. So it is not surprising that teenagers have a tendency to adopt information they got from their friends, without the need to have more reliable information from reliable sources - this behavior is also applied to pornographic information seeking.

Furthermore, the physical development that teenagers are experiencing triggers them to find out about the changes happening inside them, especially sexual changes. The physical development is indicated by how a teenager's reproductive organs have begun to function. For male, testosterone is produced by the testicles continuously. For females, the hormones they produced is the estrogen and the progesterone hormones, both produced in ovarium cyclically. These sex hormones cause secondary sexual development and create sexual drive. This drive is the reason why teenagers seek sexual information.

Is pornographic information useful for teenagers? From the result of this study, there are two thoughts addressing this question; the male informants stated that pornographic information is useful, and the female informants stated otherwise. The researcher for this study argues that the benefit felt by male informants is because they got sexual information from pornography. As we know, society sees that giving sex information to teenagers is taboo. The discussion about sex is taboo or not appropriate to be done in our culture because sex is personal. There is also the assumption that if teenagers have enough information about sex, especially reproductive health services, they would be motivated to do sexual activity and early promiscuity. Talking about sex with teenagers is equal to asking them to try.

Meanwhile, the researchers see that the reason of why the female respondents claim that pornographic information has no benefit at all is that the female respondents are trying to fight the women's body exploitation in pornographic information. Because as we understand, pornography often exploited women's body part to stimulus sexual desires.

As stated previously, peer-group is a source of pornographic information for teenagers. The researchers argue that peer-group will form a group identity. To improve the sense of social identity, the formulation of rules and collective agreements is carried out, which is called norms. These norms are needed by group members in the society to protect themselves from the violation of rights by people or groups or other parties, protect themselves from accidents, protect themselves from embarrassment and et cetera.

Furthermore, norms that are formed inside their social group creates subjective norms, the individual beliefs of what does essential people in their circles expect from them. In the theory of planned behavior (Ajzen, 1991), it is stated that an individual's subjective norms will create normative beliefs, the beliefs that when somebody does not adhere to their group norms/rules, they are punishable by social consequences or moral consequences. Research articles published by David, Dohyun , and Hutagalung (Ahn, 2010; David, 2005; Hutagalung, 2016b) strengthen Ajzen (1991)'s theory of how group norms could affect selective exposure.

The social identity theory could be used to help explains how the group support/pressure could affect beliefs. Through the social identity theory, Tajfel and Turner established that membership in a group creates in-group/self-categorization. Tajfel and Turner defined a social group as two individuals or more, which have shared social identity or see themselves as a member of the same social category (Tajfel, H., \& Turner, 1979).

Sheriff $(1936,1937)$ 's research which is also known as the autokinetic light effect Solomon Asch (1995)'s research about the creation of group norms could also show that an individual tends to depend on other people/group in order to have a belief. Both pieces of research done by both expert proved that group has a very significant influence in the beliefforming process. Group pressure has a very significant effect on belief settlement of an 
assessment or an individual decision-making process, even if there is information that contradicts this individual's logical thoughts (Severin \& Tankard Jr., 2001).

From the exploration of past researches previously discussed, it can be concluded that the group has a role in selective exposure. The pressure created by groups towards an individual belief(s) is very depended on how close the individual with the group and how big is the individual's need to belong in that group. The closer and the needier an individual is, the more significant the group influence their beliefs.

The result of this study shows that the informants agreed on how peer-group could create group norms, but if the group norms contradict their boarding school rules, the informants will choose to adhere to the boarding school rules instead. This is possible because the informants have a closer attachment and more significant needs with the boarding school compared to their peer group.

In the case of pornography, when reality (in this case the boarding school) is in-line with the belief that someone has regarding the selection or the avoidance of pornography, then their belief would not change. Vice versa, when the reality sees pornography as usual but belief rejected pornography; then belief could change. The change of belief is depended on how close the interactional relationship between an individual and its reality. The closer the relationship, the faster the belief(s) change, and vice versa. The change that happened is a means to achieve cognitive balance.

\section{Conclusion}

This research was grounded on the starting point of "What is the peer-group role in the process of pornographic information selection and avoidance by teenagers in a modern Islamic Boarding School?"'

Pornography was used as a research object because of how pornography is a serious problem in Indonesia, which has iceberg property, which, in turn, requires special attention. Teenagers were used as respondents because teenagers are the most significant population that is targeted by pornography industries.

The result of this study shows that peer group pressure has a low impact on an individual selection or avoidance of pornographic information, compared to the pressure from the boarding school as a study group. According to the researcher, the existence of the selection or avoidance of pornographic content which is based on the boarding school group influence for an individual is a way for this particular individual to achieve balance with their social environment. Because deviation from a group often causes punishment, whether moral/social or legal.

The result of this study is in accordance with the original thought of Festinger about the cognitive dissonance theory (the basis of the selective exposure theory) which stated that group has a vital role in the process of cognitive dissonance. According to Festinger, a group could be the source of information which causes dissonance (dissonance-arousing information) or even to reduce dissonance (dissonance-reducing information). In order to achieve consonance, people tend to select the information that is in-line with group decision and avoid information that their group will probably reject.

The result of this study also strengthens the theory of consonance and dissonance which popularized by McQuail (McQuail, 1996), which is a model that illustrates how an individual could have a tendency to avoid media sources that have the possibility to increase dissonance 
accept media sources that have the possibility to increase consonance. And as a social being, individuals will process information by incorporating both self cognitive system and the social environment around them.

\section{References}

[1]. Ahn, D. (2010). The Appeal of Tragic Drama to Lonely Individuals: Selective Exposure to Media Content.

[2]. Ajzen, I. (1991). The theory of planned behavior.

[3]. Anisah, N. (2016). Efek Tayangan Pornografi di Internet Pada Perilaku Remaja di Desa Suka Maju Kecamatan Tenggarong Seberang. Efek Tayangan Pornografi Di Internet Pada Perilaku Remaja Di Desa Suka Maju Kecamatan Tenggarong Seberang, 4(1).

[4]. Damayanti. (2007). Peran Biopsikososial Terhadap Perilaku Berisiko Tertular HIV Pada Remaja SLTA Di DKI Jakarta,.

[5]. David, J. (2005). Television and Theories of Selective Exposure: Review and Directions for Future Research.

[6]. Festinger, L. (1957). A theory of cognitive dissonance. Scientific American. https://doi.org/10.1037/10318-001

[7]. Fischer, Peter, et. al. (2011). Threat and Selective Exposure: The Moderating Role of Threat and Decision Context on Confirmatory Information Search After Decisions. Journal of Experimental Psychology, 140(1).

[8]. Fishbein, M., \& Ajzen, I. (1975). Belief, Attitude, Intention, and Behavior: An Introduction to Theory and Research.

[9]. Griffin, E. (2009). A First Look At Communication Theory.

[10]. Hutagalung, I. (2016a). . Pola Pemikiran dan Penolakan Informasi Pornografi di Kalangan Remaja. Journal Communication.

[11]. Hutagalung, I. (2016b). Selective Exposure And Consumer Behavior - Interpretative Phenomenological Analysis In Consumer Behavior Of Z Generation Adolescent On The Ad Information Of Smartphone Selection. The International Journal of Organizational Innovation, 9(2), 85-91.

[12]. Hutagalung, I. (2017). The Utility of Information in Selective Exposure of Pornography Among Teenagers in Indonesia. International Journal of Social Relevance \& Concern, 5(5).

[13]. Hutagalung, I. (2018). The Utility of Information in Selective Exposure of Pornography Among Teenagers in Indonesia. International Journal of Social Relevance \& Concern, 5(5).

[14]. Littlejohn, S., \& Foss, K. A. (2009). Theories of Human Communication.

[15]. Mahsiani, L. (2018). Is Parental Communication or Internet use that makes Pornography in Teenagers? Journal Child Development Studies, 3(1).

[16]. McQuail, D. (1996). Teori Komunikasi.

[17]. Miller, K. (2005). Organizational communication. Communication Education (Vol. 33). https://doi.org/10.1080/03634528409384739

[18]. Sarwono, S. (n.d.). Psikologi Sosial: Individu dan Teori-Teori Psikologi Sosial.

[19]. Severin, W. J., \& Tankard Jr., J. W. (2001). Communication Theories. Critical Perspectives, 61. https://doi.org/10.1017/CBO9781107415324.004

[20]. Supriati, E., \& Fikawati, S. (2009). Efek Paparan Pornografi Pada Remaja SMP Negeri Kota Pontianak Tahun 2008 Effect of Pornography Exposure on Junior High School Teenagers of Pontianak in 2008. Makara. Sosial Humaniora, 13(1), 48-56. Retrieved from http://journal.ui.ac.id/index.php/humanities/article/viewFile/210/206

[21]. Tajfel, H., \& Turner, J. C. (1979). An Integrative Theory of Intergroup Conflict.

[22]. Zillmann, D., \& Bryant, J. (1985). Selective exposure to communication. In Cognitive dissonance in selective exposure (pp. 11-33). 